\title{
Regional warming from aerosol removal over the United States: Results from a transient 2010-2050 climate simulation
}

\author{
L.J. Mickley ${ }^{\mathrm{a}, *}$, E.M. Leibensperger ${ }^{\mathrm{a}, \mathrm{b}}$, D.J. Jacob ${ }^{\mathrm{a}}$, D. Rind ${ }^{\mathrm{c}}$ \\ ${ }^{a}$ School of Engineering and Applied Sciences, Harvard University, 29 Oxford Street, Cambridge, MA 02138, USA \\ ${ }^{\mathrm{b}}$ Department of Earth, Atmospheric, and Planetary Sciences, Massachusetts Institute of Technology, Cambridge, MA, USA \\ ${ }^{\mathrm{c}}$ Goddard Institute for Space Studies, New York, NY, USA
}

\section{A R T I C L E I N F O}

\section{Article history:}

Received 13 May 2010

Received in revised form

17 July 2011

Accepted 18 July 2011

\section{Keywords:}

Regional climate change

Pollution

Short-lived species

Air quality

Particulate matter

\begin{abstract}
A B S T R A C T
We use a general circulation model (NASA Goddard Institute for Space Studies GCM 3) to investigate the regional climate response to removal of aerosols over the United States. We perform a pair of transient 2010-2050 climate simulations following a scenario of increasing greenhouse gas concentrations, with and without aerosols over the United States and with present-day aerosols elsewhere. We find that removing U.S. aerosol significantly enhances the warming from greenhouse gases in a spatial pattern that strongly correlates with that of the aerosol. Warming is nearly negligible outside the United States, but annual mean surface temperatures increase by $0.4-0.6 \mathrm{~K}$ in the eastern United States. Temperatures during summer heat waves in the Northeast rise by as much as $1-2 \mathrm{~K}$ due to aerosol removal, driven in part by positive feedbacks involving soil moisture and low cloud cover. Reducing U.S. aerosol sources to achieve air quality objectives could thus have significant unintended regional warming consequences.
\end{abstract}

(c) 2011 Elsevier Ltd. All rights reserved.

\section{Introduction}

Atmospheric aerosols affect climate directly, through scattering and absorption of sunlight, and indirectly, by providing cloud condensation nuclei. Increasing anthropogenic aerosols have exerted a significant cooling effect over the past century (Forster et al., 2007; Myhre, 2009; Murphy et al., 2009), mitigating in part the warming due to greenhouse gases (e.g., Hansen et al., 2007). U.S. emissions of aerosols and their precursors are presently declining sharply due to policies aimed at air quality and acid rain (Streets et al., 2004; Environmental Protection Agency, 2006). The regional climate effect could potentially be large since the presentday direct radiative forcing over the United States from anthropogenic aerosols is about $-2 \mathrm{~W} \mathrm{~m} \mathrm{~m}^{-2}$, similar in magnitude but opposite in sign to the globally averaged anthropogenic greenhouse forcing (Liao et al., 2004; Koch et al., 2007; Shindell et al., 2007; Forster et al., 2007). However, the connection from regional forcing to regional climate response is not well understood (National Research Council, 2005). We use here a general circulation model (GCM) in a 2010-2050 transient-climate simulation to investigate the climate response to suppression of U.S. aerosol sources.

\footnotetext{
* Corresponding author. Tel.: +1 6174965635.

E-mail address: mickley@fas.harvard.edu (L.J. Mickley).
}

Ground-based observations of clear-sky solar radiation over the United States reveal a surface dimming of $-2 \mathrm{~W} \mathrm{~m}^{-2}$ per decade over 1960-1990 (Liepert and Tegen, 2002). This trend reversed to a brightening of $+5 \mathrm{~W} \mathrm{~m}^{-2}$ per decade between 1995 and 2007 (Long et al., 2009). U.S. trends in the sources of anthropogenic aerosols roughly follow these trends in insolation (Lefohn et al., 1999; van Aardenne et al., 2001; Streets et al., 2006; Bond et al., 2007). For example, the EDGAR inventory shows U.S. sulfur emissions increasing by 30\% from 1950 to 1980 and then returning to1950s values over the next two decades (van Aardenne et al., 2001; Olivier and Berdowski, 2001). Volcanic aerosol from the eruptions of El Chichon (1982) and Mount Pinatubo (1991) likely contributed to transient surface cooling but with little impact on the above long-term trends (Wild et al., 2005; Wild, 2009).

Observations suggest that declining aerosols over Europe contributed to an observed continental surface warming of $1 \mathrm{~K}$ for 1980-2006 (Ruckstuhl et al., 2008; Philipona et al., 2009). All-sky solar radiation at the surface increased by about $+2 \mathrm{~W} \mathrm{~m}^{-2}$ during this time period in Europe, concurrent with a $60 \%$ decline in regional aerosol optical depths (AOD) (Ruckstuhl et al., 2008). Philipona et al. (2009) found that the 1980-2006 shortwave forcing due to aerosol decline was 2-3 times larger over the continent than the concurrent longwave forcing due to rising anthropogenic greenhouse gases. Over India, the aerosol burden has increased dramatically in recent decades, yielding surface forcings as large as -15 to $-25 \mathrm{~W} \mathrm{~m}^{-2}$ in some regions during the 
dry season (Krishnan and Ramanathan, 2002; Ramana et al., 2004). Krishnan and Ramanathan (2002) provide observational evidence of a $0.5 \mathrm{~K}$ cooling over India since the 1970 s due to increasing aerosols. Over the United States, surface temperatures rose $\sim 1 \mathrm{~K}$ from 1980 to 2006 after having remained flat from 1960 to 1980 [http://www.ncdc.noaa.gov], though no study to date has attempted to relate this rate of warming to U.S. aerosol forcings.

In a closed system, regional radiative forcing from anthropogenic aerosols would cause a collocated climate response over the source continent. Horizontal transport of heat dilutes the response (National Research Council, 2005). Several GCM studies have reported that the pattern of surface temperature response from global aerosol trends closely matches that from warming by the well-mixed greenhouse gases (Harvey, 2004; Levy et al., 2008; Shindell et al., 2008; Koch et al., 2009; Kloster et al., 2010). A recent U.S. government report concluded that regional control strategies for short-lived species such as aerosols would have mostly global (rather than regional) impacts on climate (Climate Change Science Program, 2008). However, this conclusion does not seem consistent with the observed correlations between temperature and aerosol trends in source regions. Some GCMs do show strong regional cooling effects from anthropogenic aerosols, such as a $0.4 \mathrm{~K}$ annual mean cooling over India (Ramanathan et al., 2005) and a 0.5-1.0 K mean summertime cooling over China (Menon et al., 2002). Using a regional model, Jacobson et al. (2007) calculated a $0.5 \mathrm{~K}$ cooling over Los Angeles in winter due to anthropogenic aerosols.

Here we use the Goddard Institute for Space Studies (GISS) GCM 3 (Rind et al., 2007) to compare 2010-2050 temperature trends in a simulation with present-day U.S. aerosols vs. a simulation with no U.S. aerosols. We focus on only the direct aerosol effect. Our simple approach of zeroing AOD permits detailed analysis of a suite of meteorological changes, including feedback processes and the seasonality of the climate response. Also, by performing a transient model simulation with changing greenhouse gases, we test whether the interaction of aerosol and greenhouse gas effects has importance.

\section{Approach}

We use the GISS GCM 3 with $4^{\circ} \times 5^{\circ}$ horizontal resolution and 23 levels in the vertical (Rind et al., 2007). The climate sensitivity of this GCM to a doubling of $\mathrm{CO}_{2}$ is $2.8 \mathrm{~K}$ (Rind et al., 2007), within the 2.1-4.4 K range of current models (Randall et al., 2007). Heat exchange with the ocean uses a Q-flux scheme, in which sea surface temperatures respond to changing climate but the horizontal transport of heat in the ocean is set to present-day values (Hansen et al., 1988). The scheme allows for diffusive mixing of heat into the deep ocean (Hansen et al., 2002). The Q-flux approach is widely used to perform ensemble and sensitivity studies (Jones et al., 2007; Ming and Ramaswamy, 2009). The forcing from U.S. aerosols is sufficiently small that it should not perturb ocean circulation significantly.

For present-day aerosol loading, we use monthly mean 1990s AODs at $550 \mathrm{~nm}$ from Hansen et al. (2002); the annual mean AOD is shown in Fig. 1a. Aerosol mass concentrations over the United States have declined since the 1990s (Smith et al., 2011; Environmental Protection Agency, 2010; Leibensperger et al., submitted for publication), and so the climate response we calculate here may have already begun to take place. Over the United States, the 1990s AOD in the model averages 0.2 , of which $90 \%$ is anthropogenic. About half the AOD is due to sulfate aerosols; the other main components are organic carbon ( $40 \%)$ and black carbon $(\sim 10 \%)$. The mean single-scattering albedo is 0.93 . Only the direct radiative effect of aerosols is included in the model. Our understanding of indirect effects involving aerosol-cloud interactions is poor (Forster et al., 2007) and not including them makes our study conservative. Philipona et al. (2009), in their analysis of surface radiative fluxes over Europe, found no significant trends in cloud cover linked to changing AOD.

Fig. 1b shows the annually averaged, top-of-atmosphere (TOA) direct radiative forcing from zeroing present-day aerosols over the United States, calculated as in Mickley et al. (1999). The forcing is
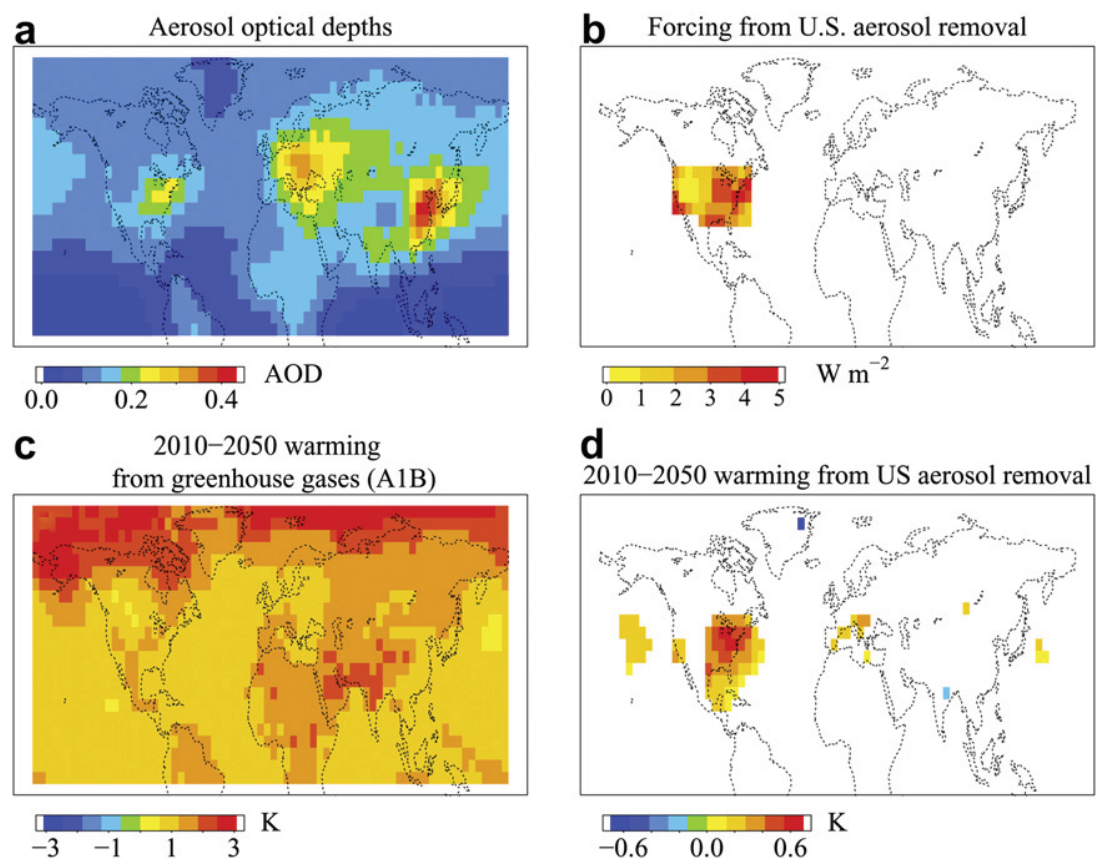



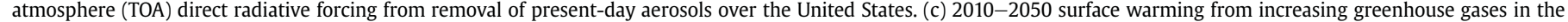


temperatures. (d) Additional 2010-2050 annual mean warming from removal of US aerosols. White areas show statistically insignificant temperature change. 
positive, due to the removal of cooling aerosols, and is mainly in the shortwave. It averages $2.2 \mathrm{~W} \mathrm{~m}^{-2}$ over the United States, within the range of published studies (e.g., $2 \pm 0.5 \mathrm{~W} \mathrm{~m}^{-2}$ in the multi-model study of Schulz et al. (2006)) and comparable to that derived from satellite and ground-based measurements (Chung et al., 2005). Over the Northeast and California the forcing is as large as $5 \mathrm{~W} \mathrm{~m}^{-2}$, again in good agreement with observed values (Chung et al., 2005). The surface forcing averages $5.2 \mathrm{~W} \mathrm{~m}^{-2}$ over the United States, larger than the TOA forcing because of aerosol absorption of solar radiation, and is as large as $8 \mathrm{~W} \mathrm{~m}^{-2}$ over the Northeast and California (not shown).

We perform 2010-2050 transient-climate simulations for the four cases in Table 1, including calculations for 3 ensemble members for each case. Control Simulation 1 follows the IPCC A1B scenario for the well-mixed greenhouse gases, with AOD fixed at present-day levels. The A1B scenario is characterized by rapid economic growth, new energy-efficient technologies, and energy generation from a balanced mix of fossil fuel and alternative sources (Nakicenovic et al., 2000). Control Simulation 2 uses fixed 2010 greenhouse gases and present-day AOD. Sensitivity Simulation 1 follows the A1B scenario for well-mixed greenhouse gases but with the AOD over the United States set to zero starting in 2010. Sensitivity Simulation 2 uses fixed 2010 greenhouse gases as in Control Simulation 2, but zeroed AOD as in Sensitivity Simulation 1.

Our approach does not consider the radiative effect of U.S. aerosols transported outside the United States, and does not separate natural and anthropogenic contributions to the AOD. Most of the AOD from U.S. aerosol sources is over the United States itself (Fig. 1a), reflecting the short lifetime of aerosols against rainout. As stated above, anthropogenic sources account for $90 \%$ of the AOD over the United States in the Hansen et al. (2002) data. As a test, we conducted a 2010-2050 transient-climate simulation in which we zeroed only the anthropogenic component of the AOD. We found no significant differences in regional climate response relative to the case in which we zeroed total AOD.

All simulations are initialized in 2010 with results from a previous transient 1950-2010 climate simulation using the same GCM (Wu et al., 2008), and ensemble members are generated by varying the initial set of random numbers used in the calculation of fractional cloud cover. Unless otherwise specified, results for each case are reported as averages of the ensemble members.

We used the two-tailed $t$-test to determine the significance of differences between the simulations, with $p<0.05$ as a threshold for significance. To calculate variances over the 41 model years, we used the residuals obtained as the difference between the time

Table 1

2010-2050 transient-climate GCM simulations.

\begin{tabular}{|c|c|c|c|c|}
\hline & \multirow{2}{*}{$\begin{array}{l}\text { Scenario for } \\
\text { well-mixed } \\
\text { greenhouse } \\
\text { gases }\end{array}$} & \multirow{2}{*}{$\begin{array}{l}\text { Aerosol } \\
\text { optical depths }\end{array}$} & \multicolumn{2}{|c|}{$\Delta T_{\text {surface }}, K^{\mathrm{a}}$} \\
\hline & & & Global & Eastern U.S. $^{\text {b }}$ \\
\hline Control Simulation 1 & A1B & Present-day $^{\mathrm{c}}$ & 1.4 & $1.5 \pm 0.2$ \\
\hline Control Simulation 2 & 2010 (fixed) & Present-day & 0.5 & $0.5 \pm 0.2$ \\
\hline Sensitivity Simulation 1 & A1B & $\begin{array}{l}\text { Zero over US, } \\
\text { present-day } \\
\text { elsewhere }\end{array}$ & 1.4 & $2.0 \pm 0.2$ \\
\hline Sensitivity Simulation 2 & 2010 (fixed) & $\begin{array}{l}\text { Zero over US, } \\
\text { present-day } \\
\text { elsewhere }\end{array}$ & 0.5 & $1.0 \pm 0.1$ \\
\hline
\end{tabular}

a Annual mean surface temperature change from 2000-2009 to 2041-2050. Standard deviations are from the three ensemble members, and are less than $0.1 \mathrm{~K}$ for global differences.

b Region defined by $90-70 \mathrm{~W}, 28-48 \mathrm{~N}$.

c As shown in Fig. 1a. series of each ensemble member and the 9-year moving average for the ensemble. (For the first and last 4 years of the time series, we used the average of the first and last 9 years, respectively.) In calculating significance, we also adjusted the sample size, or degrees of freedom, to account for autocorrelation within each ensemble member. For this, we followed the formulation of Wilks (2006):

$N_{\text {adjusted }}=\sum_{i=1}^{n} N_{i}\left(1-\alpha_{i}\right) /\left(1+\alpha_{i}\right)$,

where $N_{\text {adjusted }}$ is the adjusted degrees of freedom, $n=3$ is the number of ensemble members, $N_{i}$ is the sample size for each ensemble member (41 years), and $\alpha_{i}$ is the lag- 1 year autocorrelation coefficient of the residuals of the 9-year moving average of the time series for each member. For surface temperature, the time scale of autocorrelation of the 9-year moving average is about one year.

\section{Climate response to removal of U.S. aerosols}

All four simulations in 2010 are out of radiative equilibrium, with some residual warming from the 1950-2010 spin-up stored in the ocean. By 2041-2050, Control Simulation 2 with constant greenhouse gases shows a global surface warming of $0.5 \mathrm{~K}$ relative to the spin-up years, 2000-2009. By contrast, Control Simulation 1 with increasing greenhouse gases shows a global surface warming of $1.4 \mathrm{~K}$ by $2041-2050$, as shown in Fig. 1c. As is typical of future climate calculations, warming is strongest over high northern latitudes $(+2-3 \mathrm{~K})$. Warming over the contiguous United States averages about $1 \mathrm{~K}$.

Fig. $1 \mathrm{~d}$ shows the additional surface warming caused by removing aerosols over the United States, as obtained by difference between the mean 2010-2050 surface temperatures in the Sensitivity Simulation 1 and Control Simulation 1 . This additional warming is mainly localized over the eastern United States, strongly correlated with the pattern of forcing (Fig. 1b). It reaches $0.4-0.6 \mathrm{~K}$ in that region, with a maximum of $0.6-0.8 \mathrm{~K}$ in the late summer/early fall timeframe, as will be discussed below. About $0.2 \mathrm{~K}$ of significant warming occurs downwind over Europe and also upwind in the region of the Pacific High. Surface cooling or warming in isolated gridboxes elsewhere across the Northern Hemisphere is likely due to noise. White areas indicate regions where temperature changes were not statistically significant. In general, the pattern of surface warming is in accordance with the regional character of the radiative forcing.

In Fig. 2, we present the time series of annual mean surface temperatures for Control Simulation 1 and Sensitivity Simulation 1 averaged over the eastern United States. Temperatures are shown as the anomalies relative to the 2000-2009 mean. There is large interannual variability: the standard deviation of the residuals of the 9-year moving average for any one ensemble member is $\sim 1 \mathrm{~K}$. The bold curves in Fig. 2 show the running 9-year means of the ensemble averages for the control and sensitivity simulations. In both cases the annual mean temperatures climb by about $0.8 \mathrm{~K}$ during the 40-year simulation, due to rising greenhouse gases, but the simulation with zero U.S. aerosols shows a positive offset of $0.5 \mathrm{~K}$ that develops immediately and persists over the course of the simulation. The offset is highly significant $(p<0.01)$, as determined by Student's $t$-test.

Fig. 3 shows the 2010-2050 annual mean response to the removal of aerosol for three measures of temperature over the U.S. domain. Fig. 3a, which shows the change of surface mean temperature, is the same as Fig. 1d, but limited to the United States. We repeat the plot here to facilitate comparison with the change in mean daily maximum temperatures (Fig. $3 \mathrm{~b}$ ). We find that the daily 




Fig. 2. Time series of annual mean surface temperatures anomalies over the eastern United States $(90-70 \mathrm{~W}, 28-48 \mathrm{~N})$ in the $2010-2050 \mathrm{~A} 1 \mathrm{~B}$ atmosphere relative to the 2000-2009 mean. The green curves represent Control Simulation 1 with fixed present-day AODs; the red curves represent the Sensitivity Simulation with U.S. aerosols removed from 2010 on. Dotted curves show results for the 3 ensemble members of each simulation. Solid curves show the running 9-year means averaged over the ensemble members.

maximum temperatures show a greater sensitivity to zeroed AOD than mean daily temperatures, with increases of $0.2-1.0 \mathrm{~K}$ over large regions in the eastern half of the United States and in the West, due to enhanced solar heating under clear skies. The response in the mean diurnal temperature range (Fig. 3c) is generally consistent with the change in daily maximum temperatures, with increases of $0.1-0.2 \mathrm{~K}$ across much of the northern United States, the West, and Texas. Comparison of Fig. $3 \mathrm{~b}$ and $\mathrm{c}$ indicates that nighttime minimum temperatures change considerably less than the mean daily maximum temperatures.

The removal of U.S. aerosol also perturbs the hydrological cycle through strong surface heating and lofting of moist air. Although annual mean total cloud cover remains unchanged, Fig. 4a shows that moist convective cloud cover increases in Sensitivity Simulation 1 by $0.5-1.0 \%$ relative to the Control over much of central and eastern United States and nearby coastal waters. Annual mean precipitation also increases by $0.2-0.3 \mathrm{~mm} \mathrm{~d}^{-1}$ in a similar spatial pattern (Fig. 4b). The greatest enhancement in precipitation occurs in spring in the Northeast $\left(0.4 \mathrm{~mm} \mathrm{~d}^{-1}\right.$, not shown). In the Southeast, springtime precipitation increases by $\sim 0.7 \mathrm{~mm} \mathrm{~d}^{-1}$, but only during extreme events - i.e., those days with total rainfall greater than two sigma from the seasonal mean.

In Fig. 5 we present the seasonality of the response to zeroed AOD for a suite of meteorological variables averaged over the northeast quadrant of the United States (box in Fig. 3a), where aerosol forcing is largest. This region, which we will henceforth call "Northeast," covers the mid-Atlantic states south to Virginia and extends westward as far as Iowa and Missouri. Fig. 5a shows that the increase in temperature is maximum in September $(0.8 \mathrm{~K}$ for daily mean and $1.0 \mathrm{~K}$ for daily maximum temperatures). The change in the diurnal temperature range to U.S. aerosol removal is insignificant in spring but rises to $0.3 \mathrm{~K}$ in August-October, indicating large daytime heating under clear skies. In the rest of the panels of Fig. 5, we examine the positive feedbacks that result in the strong enhancement of daytime surface temperatures in late summer/ early fall.

Fig. $5 c$ shows that the increase in solar radiation absorbed at the surface due to zeroing of U.S. aerosols is maximum in summer at nearly $15 \mathrm{~W} \mathrm{~m} \mathrm{~m}^{-2}$, as expected, but these large values persist through September, even as top-of-atmosphere insolation declines. The added solar heating enhances surface latent and sensible heat a Change in mean daily temperature

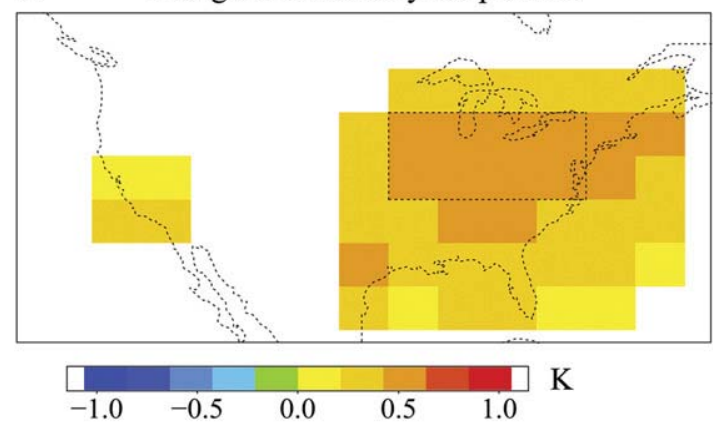

b Change in mean daily max temperature

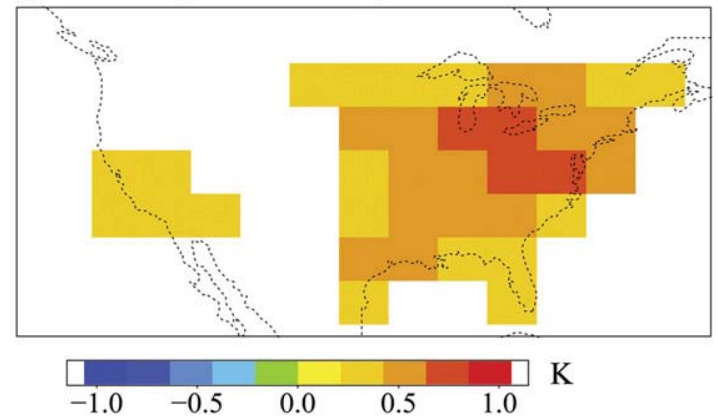

C Change in mean diurnal temperature range

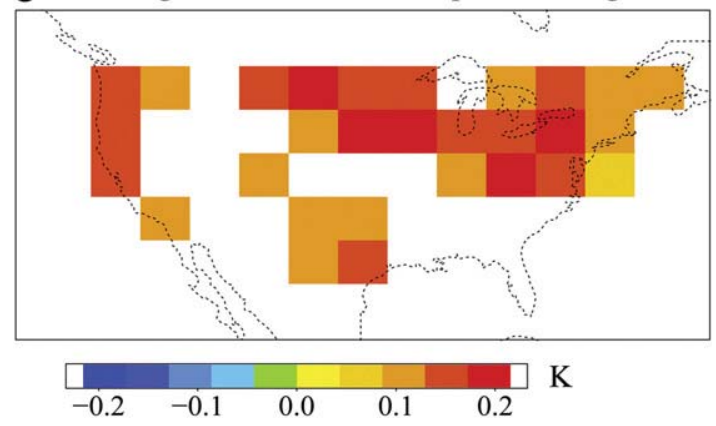

Fig. 3. Effects of removal of U.S. aerosols on (a) mean daily surface temperatures, (b) daily maximum surface temperatures, and (c) diurnal temperature range. Plots show the mean differences averaged over the 2010-2050 period between Sensitivity Simulation 1 with zeroed AOD and Control Simulation 1 with fixed present-day AOD. Panel (a) is the same as Fig. 1d, limited to the U.S. domain. White areas show statistically insignificant differences. Color bars for Panels (a) and (b) are the same.

fluxes by as much as $7-8 \mathrm{~W} \mathrm{~m}^{-2}$ and outgoing longwave radiation by $4 \mathrm{~W} \mathrm{~m}^{-2}$ (Fig. $5 \mathrm{~d}$ ). The change in latent heat flux peaks sharply in June, while the responses in sensible heat and longwave fluxes are greatest three months later in September, when declining levels of soil moisture diminish the importance of the latent heat flux in the surface energy budget. While such a loss of soil moisture occurs normally in late summer/early fall even in the absence of forcing, the enhanced solar heating in the simulation with zeroed AOD further reduces the available soil moisture in this timeframe, by about $4 \%$ (Fig. 5e). The depletion in soil moisture occurs despite the annual mean increase in precipitation rates (Fig. 4b), most of which occurs in spring. This depletion likely shifts an even larger portion of the outgoing surface energy toward sensible heat in late summer and early fall. The enhancement in sensible heat more strongly affects local surface temperatures than an equivalent increment in latent heat flux, since the latter can efficiently transport the added 



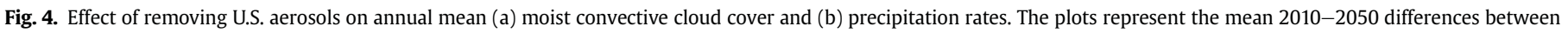

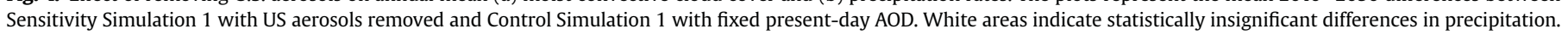

heat elsewhere (Boer, 1993; Brabson et al., 2005). Thus the decline in soil moisture contributes to a positive feedback on surface temperatures in late summer/early fall in the Northeast. By contrast, the Southeast United States does not experience significant declines in soil moisture availability.

This positive feedback in the Northeast is further augmented by changes in surface relative humidity and low cloud cover (Fig. 5f). Relative humidity at the surface exhibits a large $2 \%$ decline in the July-October timeframe owing to warmer temperatures and drier soils when U.S. aerosols are removed (Dai et al., 1999). The trend in low cloud cover follows that of surface relative humidity, as expected from observations during the warm season over the continental United States (Del Genio and Wolf, 2000). The large decline in low cloud cover in late summer/early fall in Sensitivity simulation 1 allows an even greater flux of solar energy to reach the surface, as can be seen in Fig. 5c. The net effect is to sustain the increase in surface temperatures and the diurnal temperature range through early fall (Fig. 5a and b), even as the direct forcing of aerosol declines.

In Fig. 6, we further examine the regional meteorological response to zeroed AOD in the July-September timeframe, when surface temperatures in the Northeast are most sensitive to the change in aerosol loading. Fig. 6a shows that mean July-September sea level pressures across the East drop by $2-4 \mathrm{hPa}$, owing to added surface heating. The change in sea level pressure triggers increased cyclonic circulation in the $900 \mathrm{hPa}$ wind fields. The pattern of response in moisture transport follows that of the $900 \mathrm{hPa}$ winds, with increased offshore transport of moisture from the Northeast. Although precipitation in Sensitivity Simulation 1 shows strong enhancement across the Northeast when averaged annually (Fig. 4b), in the July-September timeframe mean rainfall rates increase significantly only over nearby coastal waters, further drying out the Northeast (Fig. 6b).

We next investigate the fate of the additional heat generated at the Earth's surface, again in the July-September timeframe. Fig. 7 shows the profiles of the mean July-September 2041-2050 temperature changes over the Northeast United States for the Control Simulation 1 with fixed aerosols and the Sensitivity Simulation 1 with zeroed U.S. aerosol. The changes are calculated with respect to the 2000-2009 mean of Control Simulation 1. Warming from the A1B trend in greenhouse gases peaks at $2.0 \mathrm{~K}$ in the midtroposphere $(\sim 380 \mathrm{hPa})$, as is typical in other model studies (Meehl et al., 2007). The profile of additional heating caused by zeroed AOD shows a steep vertical gradient in the lower troposphere, with a temperature enhancement of $0.6 \mathrm{~K}$ at the surface, compared to $\sim 0.2 \mathrm{~K}$ at $660 \mathrm{hPa}$. The overlying stratosphere cools by $\sim 0.4 \mathrm{~K}$ in the simulation with zeroed AOD relative to the Control during this time period. The cooling is likely caused by a $\sim 2 \%$ enhancement in specific humidity in the mid-troposphere ( $p<0.10$, not shown) and the concomitant increase in infrared opacity.

Fig. 8 shows the mean July-September temperature response to zeroed U.S. aerosols over a larger domain at $500 \mathrm{hPa}$. At these
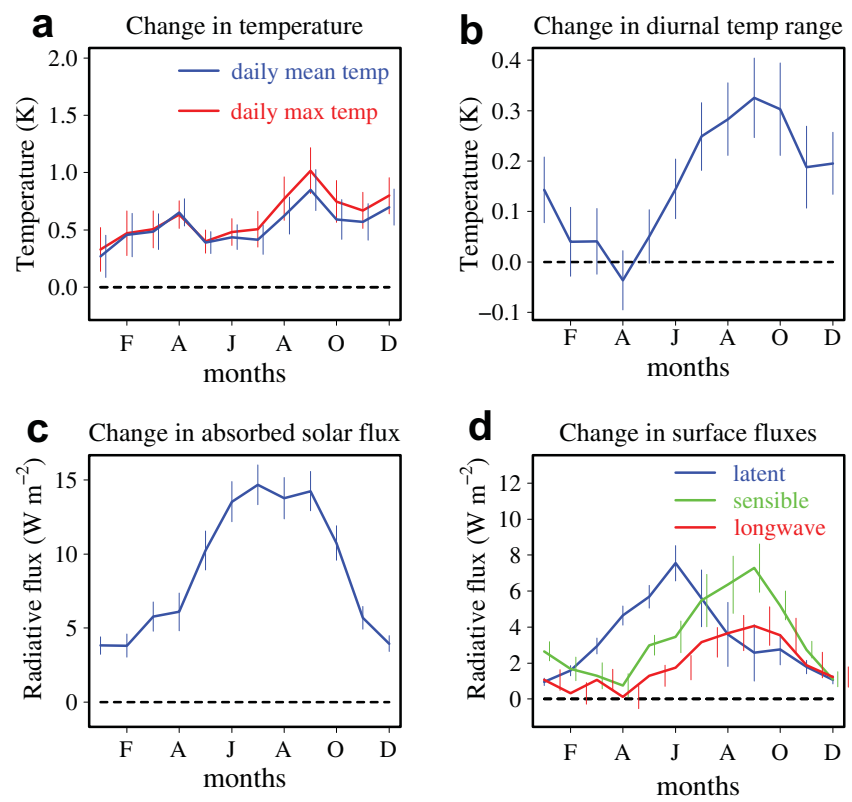

e
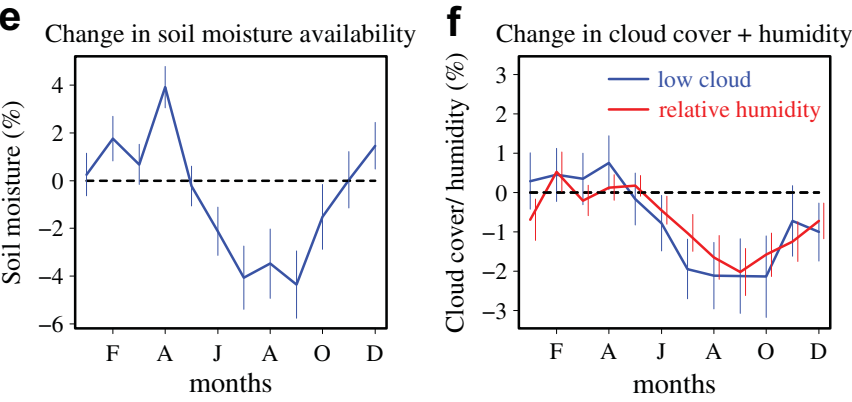

Fig. 5. Seasonal dependence in the response of several variables to removal of U.S. aerosol in the A1B atmosphere, averaged over the Northeast (box in Fig. 3a). Shown are the monthly mean differences averaged over the 2010-2050 period between Sensitivity Simulation 1 and Control Simulation 1 for (a) daily mean and daily maximum surface temperatures; (b) diurnal range in surface temperature; (c) absorbed solar flux at the surface; (d) surface fluxes of latent heat, sensible heat, and longwave radiation; (e) change in soil moisture availability; (f) low cloud cover and surface relative humidity. Positive values in Panel (d) denote increased upward flux. Percentage values in Panel (f) denote changes in absolute amount. Error bars show the standard deviation across the 41 model years and the 3 ensemble members for each case. Error bars for different curves are offset for clarity. 
a

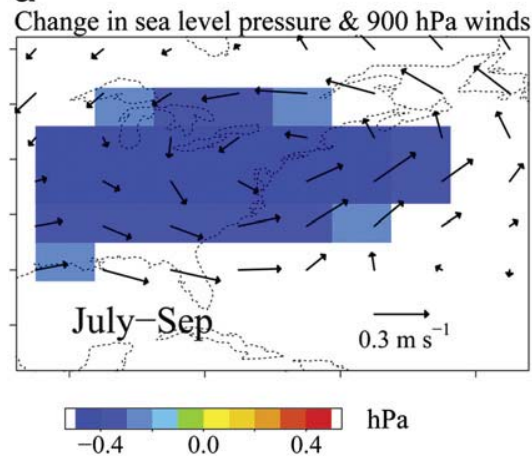

b

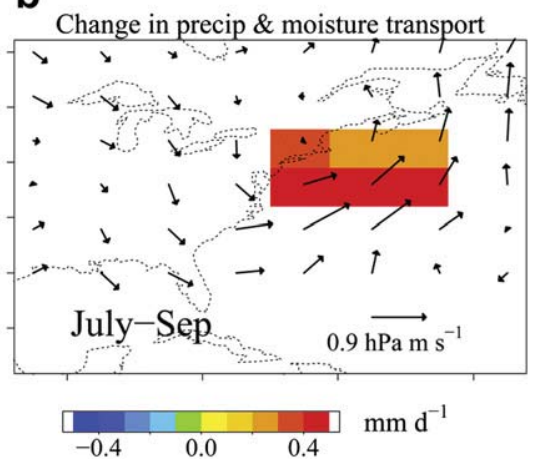

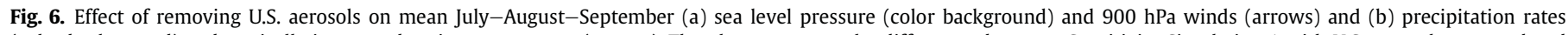

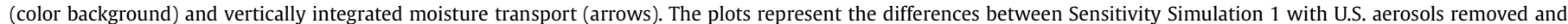



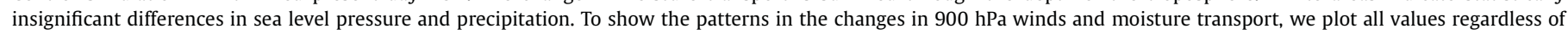
significance.

altitudes, the prevailing westerlies carry the warm air in a band stretching across the north Atlantic to Europe, with temperatures in the band averaging about $0.2-0.3 \mathrm{~K}$ greater than in the Control. Over Europe the warm air subsides, heating the surface there by about $0.5 \mathrm{~K}$ in the July-September timeframe, or about $0.2 \mathrm{~K}$ in the annual mean (Fig. 1d). Fig. 8 also shows a northward shift in the westerlies, as heating over the United States steepens the meridional temperature gradient poleward, but flattens this gradient toward the south.

We find that the removal of U.S. aerosol intensifies summer heat waves in the Northeast. Fig. 9 shows the 2010-2050 frequency distributions of daily mean surface temperature anomalies over the Northeast for July and August, when heat waves are most common. (Daily maximum temperatures are available only as monthly averages.) In Sensitivity Simulation 1 (red), with zero AOD over the United States, the median temperature increases by about $0.5 \mathrm{~K}$ relative to Control Simulation 1 (green), consistent with the change in mean July-August temperatures. But temperatures during heat waves, at the high end of the distribution, are $1-2 \mathrm{~K}$ higher in the simulation with aerosol removed. This effect is not seen in winter when aerosol radiative forcing is minimal.

In order to test whether the aerosol warming effect is contingent on A1B growth in greenhouse gases, we compared Control Simulation

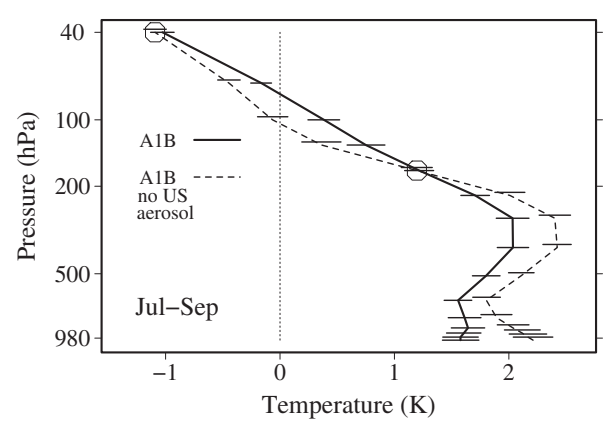

Fig. 7. Vertical profiles of the mean response of temperature to changes in greenhouse gases and aerosols, averaged over the Northeast United States (boxed region in Fig. 3a) for Jul-Aug-Sept 2041-2050, relative to 2000-2009. The bold curve represents the effect of increasing A1B greenhouse gases with constant aerosols (Control Simulation 1). The dashed curve represents the effect of the same A1B increase in greenhouse gases but with zeroed US aerosol (Sensitivity Simulation 1). Error bars show the standard deviation across the 41 model years and the 3 ensemble members for each case. Error bars have been offset for clarity. Circles denote an insignificant difference between the temperature responses in the two simulations.
2 (constant greenhouse gases and present-day AOD) with Sensitivity Simulation 2 (constant greenhouse gases but zeroed AOD over the United States). Both these simulations reach radiative equilibrium by $\sim 2025$. We find that the climate response to aerosol removal in the test simulation is similar to the response we calculate with changing greenhouse gases (Table 1). As before, the surface temperature response is immediate and an offset of $0.5 \mathrm{~K}$ remains throughout the 2010-2050 time period.

\section{Discussion}

Previous research examining the regional climate response to aerosol forcing has mainly focused on Asia, where the large aerosol burden has been estimated to reduce solar insolation by 15-25 W m ${ }^{-2}$ in some regions (Krishnan and Ramanathan, 2002; Ramana et al., 2004). Although we calculate a much weaker surface aerosol forcing over the United States in our model, about $-5 \mathrm{~W} \mathrm{~m}^{-2}$ as an annual mean, we find that removal of U.S. aerosol leads to significant regional warming, with annual mean surface temperatures increasing by $0.4-0.6 \mathrm{~K}$ in the East. During summertime heat waves in the Northeast, mean daily temperatures rise by as much as $1-2 \mathrm{~K}$. In late summer-early fall, the diurnal temperature range increases

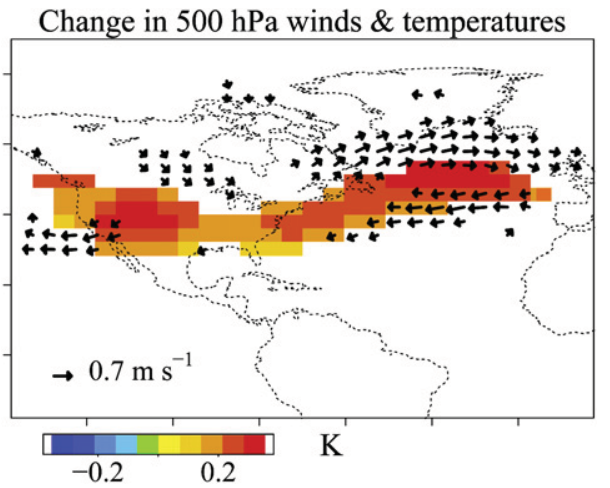

Fig. 8. Effect of removing U.S. aerosols on mean July-Aug-Sept 500-hPa temperatures (color background) and wind fields (arrows). The plots represent the mean 2010-2050 differences between Sensitivity Simulation 1 with U.S. aerosols removed and Control Simulation 1 with fixed present-day AOD. White areas indicate statistically insignificant differences in temperature. For clarity, all changes in windspeed greater than $0.3 \mathrm{~m} \mathrm{~s}^{-1}$ are shown, regardless of the significance of the difference. 


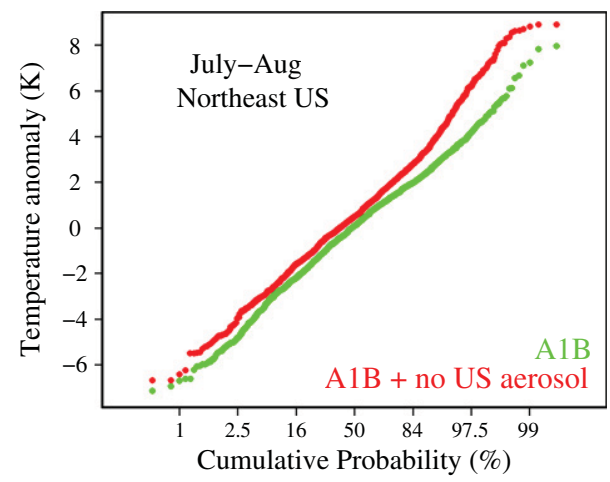

Fig. 9. Cumulative probability distributions of daily mean surface temperatures anomalies over the Northeast during July-August for the 2041-2050 period. Results are shown for Control Simulation 1 (green), with changing A1B greenhouse gases and fixed present-day aerosol burden, and for Sensitivity Simulation 1 (red), with changing A1B greenhouse gases but zeroed aerosol over the United States. Each point represents the daily mean temperature anomaly relative to the median of the Control, averaged over the Northeast for the 9 simulation years and the 3 ensemble members. The $x$-axis is a probability scale such that a normal probability distribution would plot as a straight line.

by $0.3 \mathrm{~K}$ in this region, consistent with strong daytime heating amplified by the loss of low cloud cover and depleted levels of soil moisture.

Our model results suggest that recent declines in U.S. aerosol sources (Streets et al., 2004; Smith et al., 2011) may have contributed to the observed $0.2-0.5 \mathrm{~K}$ warming over the United States in the last decade (2001-2010), relative to the previous 20 years [http://data.giss.nasa.gov]. Our finding of an increase in the diurnal temperature range when aerosol is removed is consistent with Makowski et al. (2008), who reported anticorrelations in annual mean $\mathrm{SO}_{2}$ emissions and the observed diurnal temperature ranges for several sites in Europe. For the United States, observations show a general increase in the diurnal temperature range since the 1950s (e.g., Vose et al., 2005; Zhou et al., 2009), but to our knowledge no study has examined decadal relationships in this variable and U.S. aerosol loading. Evidence of weekly cycles in the observed diurnal temperature range over many sites in the United States (Forster and Solomon, 2002) imply that anthropogenic emissions can influence daily maximum or minimum temperatures.

We identify a positive feedback occurring in the Northeast in late summer/early fall that may explain the large sensitivity of regional temperatures to aerosol forcing in our results. In this feedback, strong surface heating depletes soil moisture by midsummer, which enhances the outgoing surface fluxes of sensible heat and longwave radiation through early fall. A similar soil moisture feedback has been implicated in the 2003 European heatwave (Schar et al., 2004). Warmer temperatures and drier soils also reduce low cloud cover in the July-September timeframe, allowing more sunlight to reach the surface and increasing temperatures still further (Dai et al., 1999; Dai et al., 2006). These feedback mechanisms illustrate the importance of soil processes in governing regional climate response.

The late summer/early fall loss of soil moisture occurs with zeroed AOD despite an increase in annual mean precipitation of $\sim 0.2-0.3 \mathrm{~mm} \mathrm{~d}^{-1}$ across much of the United States. In global projections of 21 st century rainfall, the United States falls in a transition zone, with most models agreeing that precipitation will increase over latitudes north of the United States and will decrease to the south (Christensen et al., 2007). In the transition zone, models yield a more mixed picture. Our result suggests that declining aerosol sources over industrial regions in the midlatitudes may tilt the balance toward increased rainfall.
We find that the spatial pattern of surface warming over the United States strongly corresponds to the pattern of aerosol forcing. While this result is consistent with observed relationships between forcing and temperature response (Ruckstuhl et al., 2008; Krishnan and Ramanathan, 2002), it differs with some model studies reporting little spatial correlation between regional radiative forcing and surface temperature response (Brasseur and Roeckner, 2005; Shindell et al., 2007; Levy et al., 2008; Shindell et al., 2008; Liao et al., 2009). These model studies however did not separate the effects of aerosols and tropospheric ozone, combining them as an ensemble of short-lived climate forcing agents. Temperature response to ozone forcing is mainly on the hemispheric scale (Mickley et al., 2004; Yoshimori and Broccoli, 2008). In Asia and other regions of the developing world where black carbon aerosol is relatively abundant, changes in aerosol loadings lead not just to local cooling (Krishnan and Ramanathan, 2002), but also to diffuse warming since black carbon, like ozone, heats the mid- to upper troposphere (Menon et al., 2002; Zhang et al., 2009; Jones et al., 2011). By contrast, black carbon over the United States in our study accounted for only about $10 \%$ of the AOD. The indirect effect of aerosols on clouds, which was not included in our work, could further diffuse the climate response. In addition, the soil moisture feedback, which in our study intensified the local temperature response in the Northeast, may not function as effectively elsewhere. In regions with ample soil moisture, increased insolation would have less impact on temperatures (Clark et al., 2010).

A shortcoming of our approach is that we did not take into account the transport of U.S. aerosol elsewhere. In their model study, Fischer-Bruns et al. (2010) reported that Arctic surface temperatures are sensitive to changes in North American aerosol sources, and some of the previously mentioned studies also found a strong Arctic response to global trends in short-lived species (e.g., Levy et al., 2008; Shindell et al., 2008). However, Arctic aerosol pollution is dominated by transport from Asia and Europe, with U.S. sources having less influence (Stohl, 2006; Hirdman et al., 2010). Polluted air masses leaving the east coast of the United States experience lofting and diabatic heating on the warm conveyor belts prevalent in the North Atlantic, a process which washes out most aerosols (Law and Stohl, 2007; Fisher et al., 2010). The large Arctic temperature response calculated by Fischer-Bruns et al. (2010) may be partly due to the effect of global volcanic emissions, which together with North American anthropogenic aerosol sources are set to zero in their sensitivity simulation. Using a similar model as Fischer-Bruns et al. (2010), Graf et al. (1997) found that volcanic aerosol imposes forcings as great as $3 \mathrm{~W} \mathrm{~m}^{-2}$ over high northern latitudes.

Another shortcoming of this study is that the coarse model resolution we used cannot resolve orographic effects on meteorology. These effects would have greater importance in the western United States, however, than in the East. Our study also did not include a realistic variation of aerosol sources over time. Though simple, our approach of abruptly zeroing U.S. aerosol allows for greater clarity in understanding the suite of meteorological changes and feedbacks. A follow-up study (Leibensperger et al., submitted for publication) uses the same climate model to calculate the radiative forcing and climate response to historical (1950-2000) and projected (2000-2050) trends in anthropogenic aerosol sources.

The response to changing aerosol sources is likely to be modeldependent, and the robustness of our results needs to be tested with other GCMs. There is a clear need for concerted multi-model and observational studies to investigate relationships between regional aerosol radiative forcing and climate response. In particular, the sensitivity of key feedback variables such as soil moisture and low cloud cover to changing conditions needs to be better 
understood (Clark et al., 2010; Williams et al., 2006; Soden and Held, 2006). With these caveats, our results suggest that U.S. efforts to improve air quality and limit acid rain through regulation of aerosol sources could significantly exacerbate regional climate warming. Our work underscores the importance of integrating air quality and climate concerns in the design of emission control strategies.

\section{Acknowledgments}

This work was funded by the Electric Power Research Institute (EPRI) and by an EPA Science to Achieve Results (STAR) Graduate Research Fellowship to Eric Leibensperger. The EPA has not officially endorsed this publication and the views expressed herein may not reflect those of the EPA. We also thank two anonymous reviewers.

\section{References}

Boer, J.G., 1993. Climate change and the regulation of the surface moisture and energy budgets. Clim. Dyn. 8, 225-239.

Bond, T.C., Bhardwaj, E., Dong, R., Jogani, R., Jung, S., Roden, C., Streets, D.G., Trautmann, N.M., 2007. Historical emissions of black and organic carbon aerosol from energy-related combustion, 1850-2000. Global Biogeochem. Cycles 21, GB2018. doi:10.1029/2006GB002840.

Brabson, B.B., Lister, D.H., Jones, P.D., Palutikof, J.P., 2005. Soil moisture and predicted spells of extreme temperatures in Britain. J. Geophys. Res. 110, D05104. doi:10.1029/2004JD005156.

Brasseur, G.P., Roeckner, E., 2005. Impact of improved air quality on the future evolution of climate. Geophys. Res. Lett. 32, L23704. doi:10.1029/2005GL023902.

Christensen, J.H., Hewitson, B., Busuioc, A., Chen, A., Gao, X., Held, I., Jones, R., Kolli, R.K., Kwon, W.-T., Laprise, R., Magaña Rueda, V., Mearns, L., Menéndez, C.G., Räisänen, J., Rinke, A., Sarr, A., Whetton, P., 2007. Regional climate projections. In: Climate Change 2007: The Physical Science Basis. Contribution of Working Group I to the Fourth Assessment Report of the Intergovernmental Panel on Climate. Cambridge University Press, Cambridge.

Chung, C.E., Ramanathan, V., Kim, D., Podgorny, I.A., 2005. Global anthropogenic aerosol direct forcing derived from satellite and ground-based observations. J. Geophys. Res. 110, D24207. doi:10.1029/2005JD006356.

Clark, R.T., Murphy, J.M., Brown, S.J., 2010. Do global warming targets limit heatwave risk? Geophys. Res. Lett. 37, L17703. doi:10.1029/2010GL043898.

Climate Change Science Program, 2008. Climate projections based on emissions scenarios for long-lived and short-lived radiatively active gases and particles. In: Levy, H., et al. (Eds.), Department of Commerce. NOAA National Climatic Data Center, Washington, D.C., USA.

Dai, A., Trenberth, K.E., Karl, T.R., 1999. Effects of clouds, soil moisture, precipitation, and water vapor on diurnal temperature range. J. Clim. 12, 2451-2473.

Dai, A., Karl, T.R., Sun, B., Trenberth, K.E., 2006. Recent trends in cloudiness over the United States: a tale of monitoring inadequacies. Bull. Am. Met. Soc. 87, 597-606.

Del Genio, A.D., Wolf, A.B., 2000. The temperature dependence of the liquid water path of low clouds in the southern Great Plains. J. Clim. 13, 3465-3486. doi:10.1175/1520-0442.

Environmental Protection Agency, February 2006. Air Quality Criteria for Ozone and Related Photochemical Oxidants, National Center for Environmental Assessment-RTP, Office of Research and Development. U.S. Environmental Protection Agency, Research Triangle Park, NC.

Environmental Protection Agency, February 2010. Our Nation's Air: Status and Trends Through 2008, Office of Air Quality Planning and Standards. U.S. Environmental Protection Agency, Research Triangle Park, NC.

Fischer-Bruns, I., Feichter, J., Kloster, S., Schneidereit, A., 2010. How present aerosol pollution from North America impacts North Atlantic climate. Tellus 62A, 579-589.

Fisher, J.A., Jacob, D.J., Purdy, M.T., Kopacz, M., Le Sager, P., Carouge, C., Holmes, C.D., Yantosca, R.M., Batchelor, R.L., Strong, K., Diskin, G.S., Fuelberg, H.E., Holloway, J.S., Hyer, E.J., McMillan, W.W., Warner, J., Streets, D.G., Zhang, Q., Wang, Y., Wu, S., 2010. Source attribution and interannual variability of Arctic pollution in spring constrained by aircraft (ARCTAS, ARCPAC) and satellite (AIRS) observations of carbon monoxide. Atmos. Chem. Phys. 10, 977-996.

Forster, P. M. de F., Solomon, S., 2002. Observations of a "weekend effect" in diurnal temperature range. PNAS 100, 11225-11230.

Forster, P., Ramaswamy, V., Artaxo, P., Berntsen, T., Betts, R., Fahey, D.W., Haywood, J., Lean, J., Lowe, D.C., Myhre, G., Nganga, J., Prinn, R., Raga, G., Schulz, M., Van Dorland, R., 2007. Changes in atmospheric Constituents and in radiative forcing. In: Climate Change 2007: The Physical Science Basis. Contribution of Working Group I to the Fourth Assessment Report of the Intergovernmental Panel on Climate. Cambridge University Press, Cambridge.

Graf, H.F., Feichter, J., Langmann, B., 1997. Volcanic sulfur emissions: estimates of source strength and its contribution to the global sulfate distribution. J. Geophys. Res. 102, 10727-10738.
Hansen, J., Fung, I., Lacis, A., Rind, D., Lebedeff, S., Ruedy, R., Russell, G., 1988. Global climate changes as forecast by Goddard Institute for Space Studies threedimensional model. J. Geophys. Res. 93, 9341-9364.

Hansen, J., Sato, M., Nazarenko, L., Ruedy, R., Lacis, A., Koch, D., Tegen, I., Hall, T., Shindell, D., Santer, B., Stone, P., Novakov, T., Thomason, L., Wang, R., Wang, Y., Jacob, D., Hollandsworth, S., Bishop, L., Logan, J., Thompson, A., Stolarski, R., Lean, J., Willson, R., Levitus, S., Antonov, J., Rayner, N., Parker, D., Christy, J., 2002. Climate forcings in Goddard Institute for Space studies SI2000 simulations. J. Geophys. Res. 107 (4347). doi:10.1029/2001JD001143.

Hansen, J., Sato, M., Ruedy, R., Kharecha, P., Lacis, A., Miller, R.L., Nazarenko, L., Lo, K., Schmidt, G.A., Russell, G., Aleinov, I., Bauer, S., Baum, E., Cairns, B., Canuto, V., Chandler, M., Cheng, Y., Cohen, A., Del Genio, A., Faluvegi, G., Fleming, E., Friend, A., Hall, T., Jackman, C., Jonas, J., Kelley, M., Kiang, N.Y., Koch, D., Labow, G., Lerner, J., Menon, S., Novakov, T., Oinas, V., Perlwitz, Ja., Perlwitz, Ju., Rind, D., Romanou, A., Schmunk, R., Shindell, D., Stone, P., Sun, S., Streets, D., Tausnev, N., Thresher, D., Unger, N., Yao, M., Zhang, S., 2007. Climate simulations for 1880-2003 with GISS modelE. Clim. Dyn. 29, 661-696. doi:10.1007/s00382007-0255-8.

Harvey, L.D.D., 2004. Characterizing the annual-mean climatic effect of anthropogenic $\mathrm{CO}_{2}$ and aerosol emissions in eight coupled atmosphere-ocean GCMs. Clim. Dyn. 23, 569-599. doi:10.1007/s00382-004-0455-4.

Hirdman, D., Sodemann, H., Eckhardt, S., Burkhart, J.F., Jefferson, A., Mefford, T., Quinn, P.K., Sharma, S., Strom, J., Stohl, A., 2010. Source identification of shortlived air pollutants in the Arctic using statistical analysis of measurement data and particle dispersion model output. Atmos. Chem. Phys. 10, 669-693.

Jacobson, M.Z., Kaufman, Y.J., Rudich, Y., 2007. Examining feedbacks of aerosols to urban climate with a model that treats 3-D clouds with aerosol inclusions. J. Geophys. Res. 112, D24205. doi:10.1029/2007JD008922.

Jones, A., Haywood, J.M., Boucher, O., 2007. Aerosol forcing, climate response and climate sensitivity in the Hadley Centre climate model. J. Geophys. Res. 112, D20211. doi:10.1029/2007JD008688.

Jones, G.S., Christidis, N., Stott, P.A., 2011. Detecting the influence of fossil fuel and bio-fuel black carbon aerosols on near surface temperature changes. Atmos. Chem. Phys. 11, 799-816. doi:10.5194/acp-11-799-2011.

Kloster, S., Dentener, F., Feichter, J., Raes, F., Lohmann, U., Roeckner, E., FischerBruns, I., 2010. A GCM study of future climate response to aerosol pollution reductions. Clim. Dyn. 34, 1177-1194. doi:10.1007/s00382-009-0573-0.

Koch, D., Bond, T.C., Streets, D., Unger, N., 2007. Linking future aerosol radiative forcing to shifts in source activities. Geophys. Res. Lett. 34, L05821. doi:10.1029/ 2006 GL028360.

Koch, D., Menon, S., Del Genio, A., Ruedy, R., Alienov, I., Schmidt, G.A., 2009. Distinguishing aerosol impacts on climate over the past century. J. Clim. 22, 2659-2677. doi:10.1175/2008JCLI2573.1.

Krishnan, R., Ramanathan, V., 2002. Evidence of surface cooling from absorbing aerosols. Geophy. Res. Lett. 29. doi:10.1029/2002GL014687.

Law, K.S., Stohl, A., 2007. Arctic air pollution: origins and impacts. Science 315, 1537. doi:10.1126/science.1137695.

Lefohn, A.S., Husar, J.D., Husar, R.B., 1999. Estimating historical anthropogenic global sulfur emission patterns for the period 1850-1990. Atmos. Env. 33, 3435-3444.

Leibensperger, E.M., Mickley, L.J., Jacob, D.J., Chen, W.T., Seinfeld, J.H., Nenes, A., Adams, P.J., Streets, D.G., Kumar, N., and Rind D., Climatic effects of 1950-2050 changes in US anthropogenic aerosols, Part 2: Climate response. Atmos. Chem. Phys., submitted for publication.

Levy II, H., Schwarzkopf, M.D., Horowitz, L., Ramaswamy, V., Findell, K.L., 2008. Strong sensitivity of late 21 st century climate to projected changes in shortlived air pollutants. J. Geophys. Res. 113, D06102. doi:10.1029/2007JD009176.

Liao, H., Seinfeld, J.H., Adams, P.J., Mickley, L.J., 2004. Global radiative forcing of coupled tropospheric ozone and aerosols in a unified general circulation model. J. Geophys. Res. 109, D24204. doi:10.1029/2004JD005476.

Liao, H., Zhang, Y., Chen, W.-T., Raes, F., Seinfeld, J.H., 2009. Effect of chemistryaerosol-climate coupling on predictions of future climate and future levels of tropospheric ozone and aerosols. J. Geophys. Res. 114, D10306. doi:10.1029/ 2008JD010984.

Liepert, B.G., Tegen, I., 2002. Multidecadal solar radiation trends in the United States and Germany and direct tropospheric aerosol forcing. J. Geosphys. Res. 107 (D12), 4153. doi:10.1029/2001JD000760.

Long, C.N., Dutton, E.G., Augustine, J.A., Wiscombe, W., Wild, M., McFarlane, S.A., Flynn, C.J., 2009. Significant decadal brightening of downwelling shortwave in the continental United States. J. Geophys. Res. 114, D00D06. doi:10.1029/ 2008JD011263.

Makowski, K., Wild, M., Ohmura, A., 2008. Diurnal temperature range over Europe between 1950 and 2005. Atmos. Chem. Phys. 8, 6483-6498.

Meehl, G.A., Stocker, T.F., Collins, W.D., Friedlingstein, P., Gaye, A.T., Gregory, J.M., Kitoh, A., Knutti, R., Murphy, J.M., Noda, A., Raper, S.C.B., Watterson, I.G., Weaver, A.J., Zhao, Z.-C., 2007. Global climate projections. In: Climate Change 2007: The Physical Science Basis. Contribution of Working Group I to the Fourth Assessment Report of the Intergovernmental Panel on Climate. Cambridge University Press, Cambridge.

Menon, S., Hansen, J., Nazarenko, L., Luo, Y., 2002. Climate effects of black carbon aerosols in China and India. Science 297, 2250-2253.

Mickley, L.J., Murti, P.P., Jacob, D.J., Logan, J.A., Rind, D., Koch, D., 1999. Radiative forcing from tropospheric ozone calculated with a unified chemistry-climate model. J. Geophys. Res. 104, 30153-30172.

Mickley, L.J., Jacob, D.J., Field, B.D., Rind, D., 2004. Climate response to the increase in tropospheric ozone since preindustrial times: a comparison between ozone 
and equivalent $\mathrm{CO}_{2}$ forcings. J. Geophys. Res. 109, D05106. doi:1029/ 2003JD003653.

Ming, Y., Ramaswamy, V., 2009. Nonlinear climate and hydrological responses to aerosol effects. J. Clim. 22, 1329-1339.

Murphy, D.M., Solomon, S., Portmann, R.W., Rosenlof, K.H., Forster, P.M., Wong, T., 2009. An observationally based energy balance for the Earth since 1950. J. Geophys. Res. 114, D17107. doi:10.1029/2009JD012105.

Myhre, G., 2009. Consistency between satellite-derived and modeled estimates of the direct aerosol effect. Science 325 (187).

Nakicenovic, N., Alcamo, J., Davis, G., de Vries, B., Fenhann, J., Gaffin, S., Gregory, K. Grubler, A., Jung, T.Y., Kram, T., La Rovere, E.L., Michaelis, L., Mori, S., Morita, T., Pepper, W., Pitcher, H., Price, L., Raihi, K., Roehrl, A., Rogner, H.-H., Sankovski, A., Schlesinger, M., Shukla, P., Smith, S., Swart, R., van Rooijen, S., Victor, N., Dadi, Z., 2000. Special Report on Emissions Scenarios. Cambridge University Press, Cambridge.

National Research Council, 2005. Radiative Forcing of Climate Change: Expanding the Concept and Addressing Uncertainties. National Academies Press, Washington, DC.

Olivier, J.G.J., Berdowski, J.J.M., 2001. Global emissions sources and sinks. In: The Climate System. A. A. Balkema Publishers/Swets and Zeitliner Publishers, Lisse Netherlands, pp. 33-78.

Philipona, R., Behrens, K., Ruckstuhl, C., 2009. How declining aerosols and rising greenhouse gases forced rapid warming in Europe since the 1980s. Geophys. Res. Lett. 36, L02806. doi:10.1029/2008GL036350.

Ramana, M.V., Ramanathan, V., Podgorny, I.A., Pradhan, B.B., Shrestha, B., 2004. The direct observations of large aerosol radiative forcing in the Himalayan region. Geophys. Res. Lett. 31, L05111. doi:10.1029/2003GL018824.

Ramanathan, V., Chung, C., Kim, D., Bettge, T., Buja, L., Kiehl, J.T., Washington, W.M., Fu, Q., Sikka, D.R., Wild, M., 2005. Atmospheric brown clouds: impacts on South Asian climate and hydrological cycle. PNAS 102, 5326-5333.

Randall, D.A., Wood, R.A., Bony, S., Colman, R., Fichefet, T., Fyfe, J., Kattsov, V., Pitman, A., Shukla, J., Srinivasan, J., Stouffer, R.J., Sumi, A., Taylor, K.E., 2007. Climate models and their evaluation. In: Climate Change 2007: The Physical Science Basis. Contribution of Working Group I to the Fourth Assessment Report of the Intergovernmental Panel on Climate Change. Cambridge University Press, Cambridge.

Rind, D., Lerner, J., Jonas, J., McLinden, C., 2007. Effects of resolution and model physics on tracer transports in the NASA Goddard Institute for Space Studies general circulation models. J. Geophys. Res. 112, D09315. doi:10.1029/ 2006JD007476.

Ruckstuhl, C., Philipona, R., Behrens, K., Coen, M.C., Durr, B., Heimo, A., Matzler, C. Nyeki, S., Ohmura, A., Vuilleumier, L., Weller, M., Wehrli, C., Zelenka, A., 2008 Aerosol and cloud effects on solar brightening and the recent rapid warming Geophys. Res. Lett. 35, L12708. doi:10.1029/2008GL034228.

Schar, C., Vidale, P.L., Luthi, D., Frei, C., Haberli, C., Liniger, M.A., Appenzeller, C., 2004. The role of increasing temperature variability in European summer heatwaves. Nature 427, 332-336.

Schulz, M., Textor, C., Kinne, S., Balkanski, Y., Bauer, S., Berntsen, T., Berglen, T., Boucher, O., Dentener, F., Guibert, S., Isaksen, I.S.A., Iversen, T., Koch, D. Kirkevag, A., Liu7, X., Montanaro, V., Myhre, G., Penner, J.E., Pitari, G., Reddy, S. Seland, O., Stier, P., Takemura, T., 2006. Radiative forcing by aerosols as derived from the AeroCom present-day and pre-industrial simulations. Atmos. Chem. Phys. 6, 5225-5246.
Shindell, D.T., Faluvegi, G., Bauer, S.E., Koch, D.M., Unger, N., Menon, S., Miller, R.L., Schmidt, G.A., Streets, D.G., 2007. Climate response to projected changes in short-lived species under an A1B scenario from 2000-2050 in the GISS climate model. J. Geophys. Res. 112, D20103. doi:10.1029/2007JD008753.

Shindell, D.T., Levy II, H., Schwarzkopf, M.D., Horowitz, L.W., Lamarque, J.-F. Faluvegi, G., 2008. Multimodel projections of climate change from short-lived emissions due to human activities. J. Geophys. Res. 113, D11109. doi:10.1029/ 2007JD009152.

Smith, S.J., van Aardenne, J., Klimont, Z., Andres, R., Volke, A., Delgado Arias, S., 2011. Anthropogenic sulfur dioxide emissions: 1850-2005. Atmos. Chem. Phys. 11 1101-1116. doi:10.5194/acp-11-1101-2011.

Soden, B.J., Held, I.M., 2006. An assessment of climate feedbacks in coupled ocean-atmosphere models. J. Clim. 19, 3354-3360.

Stohl, A., 2006. Characteristics of atmospheric transport into the Arctic troposphere. J. Geophys. Res. 111, D11306. doi:10.1029/2005JD006888.

Streets, D.G., Bond, T.C., Lee, T., Jang, C., 2004. On the future of carbonaceous aerosol emissions. J. Geophys. Res. 109, D24212. doi:10.1029/2004JD004902.

Streets, D.G., Wu, Y., Chin, M., 2006. Two-decadal aerosol trends as a likely explanation of the global dimming/brightening transition. Geophys. Res. Lett. 33 L15806. doi:10.1029/2006GL026471.

van Aardenne, J.A., Dentener, F.J., Olivier, J.G.J., Klein Goldewijk, C.G.M., Lelieveld, J. 2001. A $1^{\circ} \times 1^{\circ}$ resolution data set of historic anthropogenic trace gas emissions for the period 1890-1990. Global Biogeochem. Cycles 15 (4), 909-928.

Vose, R.S., Easterling, D.R., Gleason, B., 2005. Maximum and minimum temperature trends for the globe: an update through 2004. Geophys. Res. Lett. 32, L23822. doi:10.1029/ 2005GL024379.

Wild, M., Gilgen, H., Roesch, A., Ohmura, A., Long, C.N., Dutton, E.G., Forgan, B. Kallis, A., Russak, V., Tsvetkov, A., 2005. From dimming to brightening: decada changes in solar radiation at the Earth's surface. Science 308, 847-850. doi:10.1126/science.1103215.

Wild, M., 2009. Global dimming and brightening: a review. J. Geophys. Res. 114, D00D16. doi:10.1029/2008JD011470.

Wilks, D.S., 2006. Statistical Methods in the Atmospheric Sciences, International Geophysics, second ed., vol. 91. Academic Press, NY.

Williams, K.D., Ringer, M.A., Senior, C.A., Webb, M.J., McAvaney, B.J., Andronova, N Bony, S., Dufresne, J.-L., Emori, S., Gudgel, R., Knutson, T., Li, B., Lo, K., Musat, I., Wegner, J., Slingo, A., Mitchell, J.F.B., 2006. Evaluation of a component of the cloud response to climate change in an intercomparison of climate models Clim. Dyn. 26, 145-165. doi:10.1007/s00382-005-0067-7.

Wu, S., Mickley, L.J., Leibensperger, E.M., Jacob, D.J., Rind, D., Streets, D.G., 2008 Effects of 2000-2050 global change on ozone air quality in the United States. J. Geophys. Res. 113, D06302. doi:10.1029/2007JD008917. http://acmg.seas. harvard.edu/publications/wu2008/2008a.pdf.

Yoshimori, M., Broccoli, A.J., 2008. Equilibrium response of an atmosphere-mixed layer ocean model to different radiative forcing agents: global and zonal mean response. J. Clim. 21, 4399-4423.

Zhang, Y., Sun, S., Olsen, S.C., Dubey, M.K., Hee, J., 2009. CCSM3 simulated regional effects of anthropogenic aerosol for two contrasting scenarios: rising Asian emissions and global reduction of aerosols. Int. J. Climatol.. doi:10.1002 joc.2060.

Zhou, L., Dai, A., Dai, Y., Vose, R.S., Zou, C.Z., Tian, Y., Chen, H., 2009. Spatial dependence of diurnal temperature range trends on precipitation from 1950 to 2004. Clim. Dyn. 32, 429-440. doi:10.1007/s00382-008-0387-5. 